\title{
KAIDAH-KAIDAH FONOLOGI
}

\author{
Susiati
}

susiatiuniqbu@gmail.com

\begin{abstract}
Abstrac
Language in literary works contains elements of beauty. Beauty is an aspect of aesthetics. This opinion is in line with Zulfahnur's opinion, language style and writing is one of the interesting elements in a reading. Each writer has a different style in pouring each of his writing ideas. Every writing that is produced later has a style of writing that is influenced by the author, so it can be said that, the character of a writer greatly influences the work he writes. This is consistent with the opinion of Pratikno (1984: 50) that the nature, character or character of a person is different. Language style is the use of a wealth of languages, the use of certain variations to obtain certain effects, the overall language characteristics of a group of literary writers and the unique way of expressing thoughts and feelings, both orally and in writing. The style of language used by the author is essentially a way of using language precisely to describe the feelings and thoughts of the author which are different from the everyday language patterns and are subjective. For this reason, we present this paper in terms of how to use language styles in general and as a wrapper for the mind.
\end{abstract}

Keyword: Languange, Styles and Experssing 
KAIDAH-KAIDAH FONOLOGI

\author{
SUSIATI \\ UNIVERSITAS IQRA BURU \\ susiatiuniqbu@gmail.com
}

\author{
MATA KULIAH FONOLOGI \\ FAKULTAS SASTRA \\ PROGRAM STUDI SASTRA INDONESIA \\ 2020
}




\section{PENDAHULUAN}

\section{Latar Belakang}

Bahasa adalah suatu fenomena yang sangat kompleks. Pendekatan kita terhadap bahasa bisa saja menganggapnya sebagai fenomena perorangan. Bila seseorang mengatakan, "Bahasanya kasar sekali”, atau "Tutur katanya menyenangkan”, maka dia secara disadari atau tidak memberikan pemerian atau menerangkan tingkah laku (human behavior) orang lain (Alwasilah, 1985: 5). Kalau kita mendengar orang berbicara, entah berpidato atau bercakapcakap, maka akan kita dengar runtutan bunyi bahasa yang terus-menerus, kadang-kadang terdengar suara menaik dan menurun, kadang-kadang terdengar hentian sejenak atau hentian agak lama, kadang-kadang terdengar tekanan keras atau lembut, dan kadang-kadang terdengar pula suara pemanjangan atau suara biasa. Runtunan bunyi bahasa ini dapat dianalisis atau disegmentasikan berdasarkan tingkatan-tingkatan kesatuannya yang ditandai dengan hentianhentian atau jeda yang terdapat dalam runtunan bunyi itu (Chaer, 2014: 100).

Bidang linguistik yang mempelajari, menganalisis, dan membicarakan runtunan bunyibunyi bahasa ini disebut Fonologi. Fonologi sebagai bidang khusus dalam linguistik, mengamati bunyi-bunyi suatu bahasa tertentu menurut fungsinya untuk membedakan makna leksikal dalam bahasa tersebut (Verhaar, 1991: 36).

Generative grammar adalah pola dari analisis terbaru yang saat ini marak di bicarakan dan bahkan dikembangkan untuk pengajaran. Dalam hal ini, fonologi generatif adalah salah satu dari bagian dari disiplin ilmu tersebut. Istilah fonologi generatif itu sendiri adalah analisis untuk menyebutkan kaidah fonologi yang melampaui batas kata. Fonologi menelaah struktur bunyi bahasa; fonologi generatif adalah teori tentang struktur ini. Kerangka teoretis yang mendasari fonologi generatif dikembangkan oleh Noam Chomsky dan Morris Halle. Fonologi Generatif secara umum membahas tiga hal yaitu; proses penelitian fonologi, proses fonologis dan kaidah-kaidah fonologis.

\section{PEMBAHASAN}

Jika kita dapat menetapkan secara tepat persyaratan untuk terjadinya proses fonologis, sebenarnya kita telah memberikan suatu kaidah. Sejauh ini, perubahan itu dinyatakan dengan bahasa sehari-hari; sekarang kita akan mengubah pernyataan ini menjadi suatu notasi formal. Notasi ini harus cocok untuk mengungkapkan jenis-jenis proses yang terjadi dalam fonologi, dan untuk mencakup generalisasi yang ditemukan di situ. Kita akan memperhatikan empat macam kaidah : 
1. kaidah perubahan ciri,

2. kaidah pelesapan dan penyisipan,

3. kaidah permutasi dan perpaduan, dan

4. kaidah bervariable.

\section{Kaidah Perubahan Ciri}

Apabila segmen mengalami perubahan, kita ingin mengetahui tiga hal, yaitu: (1) segmen mana yang akan berubah, (2) bagaimana segmen itu berubah, dan (3) dalam kondisi apa segmen itu berubah. Segmen atau kelas segmen yang mengalami perubahan digambarkan dengan perangkat ciri yang minimal untuk identifikasi yang unik. Perubahan itu juga diungkapkan dalam notasi ciri. Kemudian, segmen yang berubah dan cara perubahannya dihubungkan dengan tanda panah yang menunjuk ke arah perubahan itu.

Kedua kaidah berikut menyatakan bahwa bunyi obstruen menjadi tak bersuara dan bahwa vokal dinasalisasi.

$$
\begin{gathered}
\text { [- sonoran] } \rightarrow \text { [- bersuara] } \\
\mathrm{V} \rightarrow[+ \text { nasal] }
\end{gathered}
$$

Kaidah-kaidah ini menyiratkan bahwa semua bunyi obstruen menjadi tak bersuara dalam segala posisi, dan bahwa semua vokal dinasalisasi pada setiap kemunculannya. Akan tetapi, kebanyakan proses mempunyai batas-batas tertentu, dan perubahan itu hanya terjadi pada konteks tertentu. Garis miring digunakan untuk memisahkan lingkungan dari bagian lain kaidah itu. Jika perubahan itu terjadi dekat beberapa segmen lain, segmen-segmen ini merupakan lingkungan bagi segmen yang berubah itu.

Kaidah berikut menyatakan bahwa pada posisi antar vokal, bunyi obstruen adalah bersuara.

$$
\text { [-sonoran] } \rightarrow \text { [+bersuara] / V__ V }
$$

Dalam pembentukan kalimat umlaut, vokal dikedepankan oleh /i/ yang mengikutinya.

$$
\begin{aligned}
& \text { V } \\
& \mathrm{V} \rightarrow \text { [-belakang] / _ } \mathrm{Ko}_{\mathrm{O}}+\text { tinggi } \\
& \text {-belakang_ }
\end{aligned}
$$

Dalam kaidah ini, subskrip nol kecil pada $\mathrm{K}$ berarti bahwa mungkin tidak ada konsonan dan mungkin satu konsonan atau lebih yang ditemukan di antara vokal berumlaut dan vokal dalam lingkungan itu.

Jadi, 


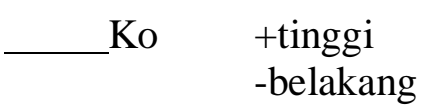

adalah singkatan dari jumlah lingkungan yang tak terbatas.

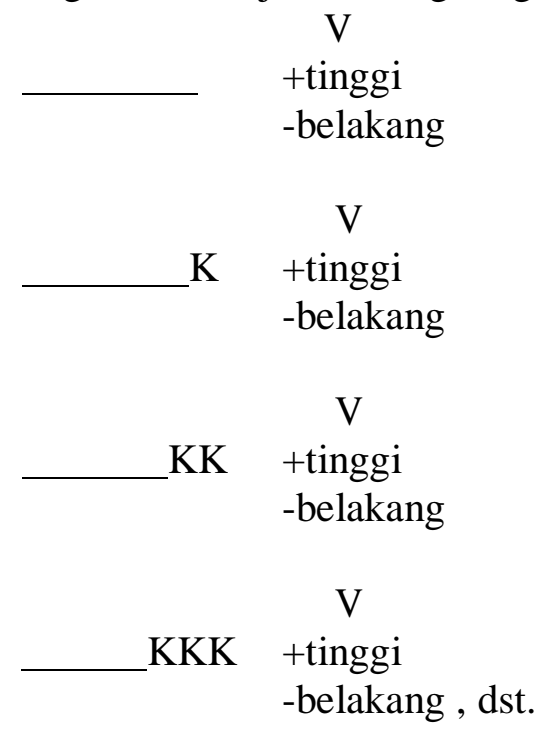

Ko selalu muncul dalam kaidah-kaidah untuk membuat pernyataan tentang vokal dari silabelsilabel yang berdampingan, tetapi tidak memperhatikan struktur konsonan dari silabel itu. Yang relevan dalam kaidah yang satu ini ialah bahwa sebuah vokal dipengaruhi oleh vokal silabel berikutnya. Jumlah konsonan (dan mungkin saja konsonan itu tidak ada) yang muncul di antara kedua vokal itu tidaklah relevan. Walaupun Ko membolehkan jumlah konsonan yang tak terbatas, tidak ada bahasa yang mempunyai lebih dari beberapa konsonan yang memisahkan vokal. Oleh karena itu, Ko harus ditafsirkan sebagai peranti notasional untuk mengungkapkan pengertian "terlepas dari jumlah konsonan”.

Segmen bukanlah satu-satunya elemen yang terdapat dalam lingkungan itu. Sering kita perlu mengetahui apakah proses itu terjadi pada awal kata atau akhir kata, pada jeda, atau pada batas morfem. Oleh karena itu, kita harus memiliki simbol untuk batas. Kita menggunakan + untuk batas morfem, \# untuk batas kata dan $\|$ untuk batas frase dan jeda.

\section{A. 1. Notasi Kurung Kurawal}

Kurung kurawal merupakan peranti yang digunakan dalam kaidah untuk merujuk ke lingkungan alternatif. Sebagai contoh dua kaidah nasalisasi vokal dalam bahasa Perancis ;

$$
\begin{aligned}
& \mathrm{V} \rightarrow[+ \text { nasal }] / \ldots \underset{\text { +nasal }}{\mathrm{K}} \mathrm{K} \\
& \mathrm{V} \rightarrow[+ \text { nasal }] / \ldots \underset{\text { +nasal }}{\mathrm{K}} \#
\end{aligned}
$$


Kedua kaidah ini serupa; keduanya menyatakan bahwa vokal itu harus diikuti konsonan nasal dan yang kemudian diikuti oleh sesuatu yang lain. Daripada mempunyai dua pernyataan terpisah untuk nasalisasi vokal, kita lebih suka sebuah pernyataan yang memperlihatkan persamaan dan perbedaan kedua proses nasalisasi itu. Dengan kata lain, kita ngin mengatakan bahwa dalam bahasa Perancis, sebuah vokal dinasalisasi jika vokal itu diikuti oleh konsonan nasal dan konsonan atau batas kata, sehingga kedua kaidah di atas menjadi;

$$
\mathrm{V} \rightarrow[+ \text { nasal }] / \ldots \underset{\text { +nasal }}{\mathrm{K}} \quad \mathrm{K}
$$

\section{A. 2. Notasi Tanda Kurung}

Tanda kurung digunakan sebagai peranti formal untuk meringkas dua kaidah yang serupa, apabila kaidah yang satu berisi spesifikasi yang tidak terdapat dalam kaidah lain, misalnya;

$$
\begin{aligned}
& \mathrm{V} \rightarrow\left[\text { +tekanan] } / \_ \text {Ko } \begin{array}{c}
\mathrm{V} \\
\text {-tegangan }
\end{array}\right. \\
& \mathrm{V} \rightarrow[\text { +tekanan]/Ko \# }
\end{aligned}
$$

Kedua kaidah itu melibatkan proses yang sama - penempatan tekanan. Keduanya berbeda hanya dalam hal kaidah pertama menyebutkan vokal kendur, sedangkan kaidah kedua tidak mempunyai spesifikasi ini. Dengan memiliki dua kaidah terpisah, kita kehilangan generalisasi ini. Notasi kurung ini memungkinkan kita membuat sebuah pernyataan tentang penempatan tekanan dalam bahasa Perancis.

$$
\mathrm{V} \rightarrow[+ \text { tekanan }] / \mathrm{Ko}_{\text {-tegang }} \mathrm{V} \quad \#
$$

\section{A. Kaidah Pelesapan dan Penyisipan}

Pelesapan dinyatakan dengan $\varnothing$, simbol nol. Segmen yang mengalami pelesapan muncul di sebelah kiri tanda panah, dan $\varnothing$ di sebelah kanan.

Dalam bahasa Prancis, konsonan nasal dilesapkan sesudah vokal nasal.

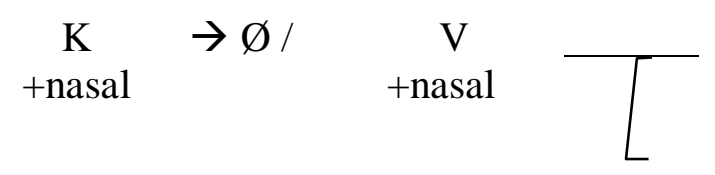<smiles>[CH]C</smiles>

Juga dalam bahasa Prancis, konsonan tertentu pada akhir kata dilesapkan jika kata berikutnya dimulai dengan konsonan atau jika konsonan itu pada posisi akhir frase.

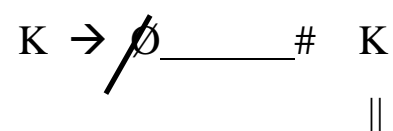




\section{B. Kaidah Permutasi dan Perpaduan}

\section{C.1. Kaidah Transformasional}

Kaidah $\mathrm{A} \rightarrow \mathrm{B} /{ }_{1} \mathrm{C}$ adalah sama dengan $\mathrm{AC} \rightarrow \mathrm{BC}$, yang lingkungannya disebutkan di kedua sisi tanda panah itu. Apabila suatu vokal mendahului konsonan nasal dan batas kata, kaidah yang menasalisasi vokal itu diberikan dalam notasi alternatif ini.

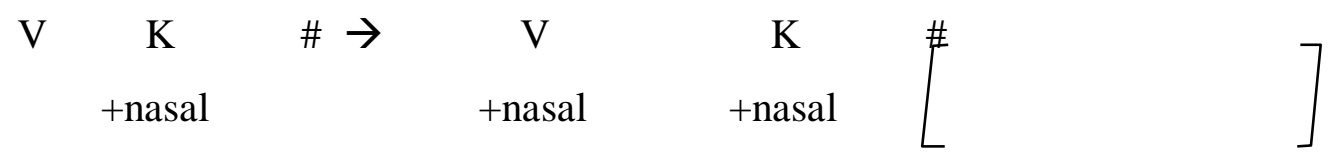

Tentu saja ada banyak pengulangan jika kaidah itu dinyatakan demikian. Konsonan nasal dan batas kata perlu diungkapkan pada kedua sisi tanda panah itu. Bahwa vokal itu telah dinasalisasi merupakan informasi baru, tetapi kenyataan bahwa vokal itu masih perlu dirinci di sebelah kanan sebagai sebuah vokal mengulangi apa yang telah diketahui di sebelah kiri. Jika kita ingin menggunakan format ini untuk menulis kaidah, kita harus menemukan notasi yang tidak perlu mengulang informasi yang sama pada kedua sisi itu. Pada dasarnya, kita ingin mengatakan bahwa jika ada tiga kesatuan dalam sebuah deretan, dan yang pertama adalah vokal, yang kedua konsonan nasal, dan yang ketiga batas kata, maka segmen pertama dinasalisasi, tetapi elemen kedua dan ketiga tetap utuh dan tak berubah. Kita dapat mengatakan ini dengan merinci dan menomori elemen yang muncul di sebelah kiri, dan menggunakan angka yang sama di sebelah kanan untuk mengacu pada posisi relatifnya. Jika salah satu segmen di sebelah kiri mengalami perubahan, perubahan itu dinyatakan di sebelah kanan bersama dengan nomor segmen itu. Untuk elemen yang tidak berubah, hanya nomor elemen itu yang muncul di sebelah kanan.

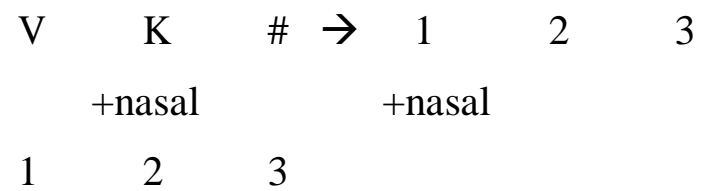

Notasi ini dapat juga digunakan untuk mengungkapkan pelesapan dan penyisipan. Untuk pelesapan, $\varnothing$ muncul di sebelah kanan tanda panah untuk menggantikan segmen yang mengalami pelesapan. Kita mengutip kaidah bahasa Perancis yang melesapkan konsonan akhir kata.

$\begin{array}{llllllll}\mathrm{K} & & \# & \mathrm{~K} & \rightarrow & \varnothing & 2 & 3 \\ & & & \| & & & & \\ & & & & & & & \\ 1 & 2 & 3 & & & & & \end{array}$




\section{Metatesis dan Perpaduan}

Dalam bahasa Hanunoo, gugus bunyi hambat glotal dan konsonan menjadi konsonan dan bunyi hambat glotal apabila gugus itu terdapat dalam kata--- yaitu antar vokal. Format transformasional ideal untuk mengungkapkan pertukaran letak semacam ini.

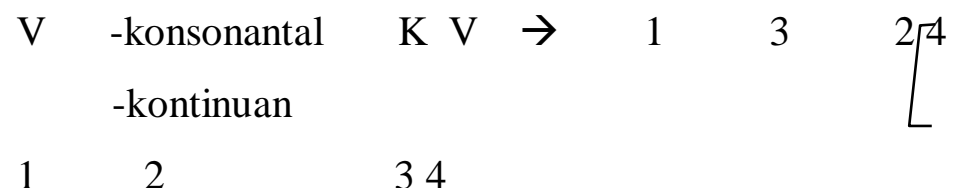

Kaidah perpaduan, yaitu dua segmen menjadi satu, perlu juga dinyatakan dalam format transformasional. Kita akan memandang perpaduan sebagai proses yang salah satu segmennya, segmen primer, dimodifikasi, sedangkan segmen sekundernya dilesapkan. Modifikasi itu dinyatakan di sebelah kanan tanda panah.

Kaidah berikut menyatakan bahwa sebuah konsonan yang diikuti oleh [w] berpadu menjadi sebuah konsonan yang dilabialisasi.

$\begin{array}{llcc}\text { K - silabis } & \rightarrow & 1 & \varnothing \\ \text { Konsonantal } & & \\ \text { + bundar - bundar } & \\ 1 & 2\end{array}$

\section{Kaidah Bervariabel}

\section{D.1. Asimilasi}

Kebanyakan gugus obstruen dalam bahasa Perancis hanya melibatkan dua konsonan. Apabila berbeda dalam penyuaraan, konsonan pertama mengasimilasikan penyuaraannya dengan konsonan kedua, misalnya, $[\mathrm{b}, \mathrm{t}] \rightarrow[\mathrm{p}, \mathrm{t}],[\mathrm{g}, \mathrm{s}] \rightarrow[\mathrm{k}, \mathrm{s}],[\mathrm{d}, \mathrm{s}] \rightarrow[\mathrm{t}, \mathrm{s}],[\mathrm{k}, \mathrm{b}] \rightarrow[\mathrm{g}, \mathrm{b}],[\mathrm{t}, \mathrm{z}]$ $\rightarrow$ [d,z]. Untuk mengungkapkan asimilasi ini, kita perlu menulis dua kaidah terpisah --yang satu menyatakan asimilsi sebelum bunyi obstruen bersuara, yang lain sebelum bunyi obstruen tak bersuara.

$$
\begin{aligned}
& \text {-sonoran } \\
& {[\text {-sonoran }] \rightarrow[+ \text { bersuara }] / \ldots[\text {-selpensanglra } \rightarrow \text { [-bersuara }] /} \\
& \text {-sonoran } \\
& \text { +bersuara }
\end{aligned}
$$

Dua kaidah yang terpisah tidak memperlihatkan generalisasi bahwa bunyi obstruen pertama selalu mempunyai penyuaraan yang sama dengan bunyi obstruen kedua. Kita ingin menyatakan generalisasi ini dengan sebuah kaidah saja. Kita dapat melihat bahwa kedua kaidah yang terpisah itu serupa. Keduanya berbeda hanya dalam nilai yang ditetapkan untuk 
ciri [bersuara] (apabila ciri itu mempunyai nilai + dalam kaidah yang satu, ciri itu akan mempunyai nilai - dalam kaidah yang lain), tetapi ciri-ciri itu sendiri tidak berbeda. Berdasarkan simetri yang lengkap dalam kedua kaidah itulah kita akan membuat generalisasi. Oleh karena itu, kita akan menggunakan notasi berikut: jika dua kaidah itu identik kecuali untuk nilai-nilai dari ciri yang sama, kedua kaidah itu dapat digantikan dengan sebuah variabel - huruf alfa Yunani - dalam kaidah baru itu.

$$
\begin{array}{cc}
\text { [-sonoran] } \rightarrow[\alpha \text { bersuara }] / \ldots & \text {-sonoran } \alpha \\
\text { bersuara }
\end{array}
$$

variabel $\alpha$ merupakan peranti formal untuk mengungkapkan pengertian "mempunyai nilai yang sama dengan" atau "nilainya bersesuaian dengan". Jadi, kaidah di atas mengatakan bahwa untuk ciri [bersuara], bunyi obstruen pertama mempunyai nilai yang sama dengan nilai pada bunyi obstruen kedua.

\section{D.2. Disimilasi}

Disimilasi adalah proses yang terjadi apabila dua segmennya menjadi kurang serupa satu sama lain. Perhatikan bahasa yang tidak membolehkan gugus bunyi-bunyi obstruen yang mempunyai cara artikulasi yang sama, sehingga konsonan hambat-hambat atau konsonan frikatif-frikatif tidak pernah ada. Konsonan hambat yang kedua dari gugus hambat-hambat digantikan dengan konsonan frikatif yang bertalian; dan konsonan frikatif kedua dari gugus frikatif-frikatif digantikan dengan konsonan hambat yang bertalian-misalnya, $[\mathrm{k}, \mathrm{p}] \rightarrow[\mathrm{k}, \mathrm{f}]$, $[\mathrm{t}, \mathrm{t}] \rightarrow[\mathrm{t}, \mathrm{s}],[\mathrm{f}, \mathrm{s}] \rightarrow[\mathrm{f}, \mathrm{t}],[\mathrm{s}, \mathrm{s}] \rightarrow[\mathrm{s}, \mathrm{t}]$. Jadi, dalam gugus obstruen, ciri [kontinuan] dari konsonan obstruen kedua harus mempunyai nilai yang berlawanan dengan nilai dalam konsonan obstruen pertama. Disimilasi ini ditangani oleh spesifikasi $-\alpha$, yang merupakan peranti formal untuk mengungkapkan pengertian "nilai yang berlawanan dengan".

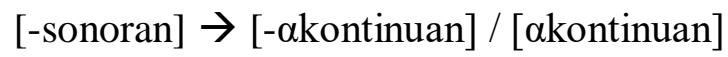

\section{D.3. Kaidah dengan Pelbagai Variabel}

Kadang-kadang sebuah segmen bisa mengasimilasi nilai-nilai yang berbeda dari dua atau lebih ciri segmen lain. Perhatikan kaidah yang umum di mana konsonan nasal menjadi homorgan dengan konsonan obstruen berikutnya, yaitu dengan mengambil nilai-nilai obstruen untuk ciri [anterior] dan [koronal]. Jika konsonan obstruen itu labial ( [+anterior, -koronal] ), konsonan nasal itu juga harus mempunyai nilai + untuk ciri [anterior] dan - untuk ciri [koronal]. Jika konsonan obstruen itu dental ( [+anterior, +koronal] ), konsonan nasal itu 
harus mempunyai nilai-nilai yang serupa. Ini juga berlaku untuk konsonan palato -alveolar 
dan velar. Kita memerluka lebih dari satu variabel untuk mengungkapkan asimilasi semacam ini. Orang menggunakan variabel sebanyak jumlah ciri yang dapat berubah-ubah dengan bebas.

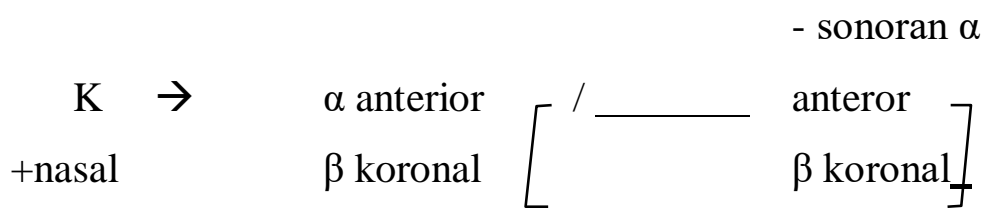

\section{D.4. Kaidah Pertukaran}

Notasi variabel digunakan untuk jenis kaidah khusus yang disebut kaidah pertukaran. Semua kaidah ini mempunyai bentuk: $[\alpha \mathrm{X}] \rightarrow[-\alpha \mathrm{X}]$. Dalam kaidah demikian, sesuatu yang pada mulanya $[+\mathrm{X}]$ akan menjadi $[-\mathrm{X}]$, sedangkan, secara serentak, sesuatu yang dimulai dengan $[-\mathrm{X}]$ akan menjadi $[+\mathrm{X}]$. Berikut ini adalah kedua kaidah pertukaran yang diterapkan satu sesudah yang lainnya. Oleh karena perubahan vokal tidak berlaku untuk $\bar{a}$, kaidah ini hanya mempengaruhi segmen yang mempunyai nilai yang sama untuk ciri [belakang] dan [bundar].

Langkah I :

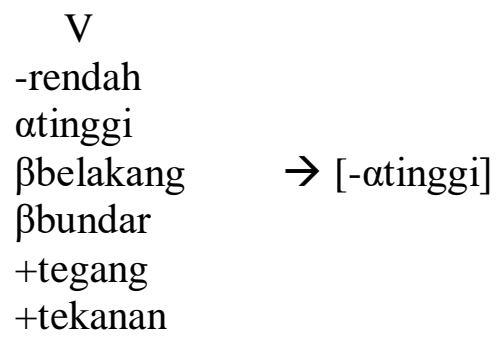

Langkah

II : $\quad$ V

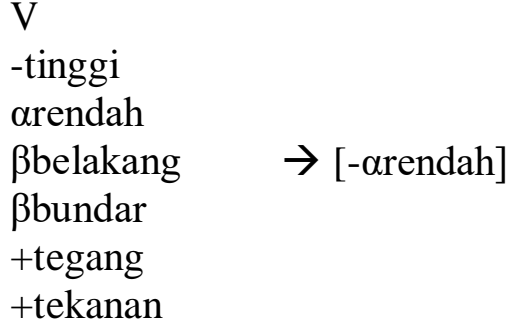

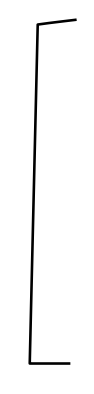

\section{D.5. Subskrip dan Superskrip}

Apabila Ko terdapat dalam sebuah kaidah, penafsirannya ialah "nol konsonan atau lebih" setiap bilangan bulat dapat muncul sebagai subskrip pada sebuah segmen, dan sekadar berarti jumlah segmen itu atau lebih. Misalnya $\mathrm{K}_{1}$ berarti satu konsonan atau lebih; $\mathrm{K}_{2}$, dua konsonan atau lebih, dst. Subskrip pada segmen menetapkan batas bawah dari jumlah segmen yang dibutuhkan untuk mengoperasikan kaidah itu. Untuk menunjukkan batas atas 


$$
1
$$$$
\begin{aligned}
& 2 \\
& 0
\end{aligned}
$$ 
digunakan superskrip. Jadi, K berarti nol atau satu konsonan; $\mathrm{K}$ antara nol dan dua konsonan, dst. Jika sebuah segmen berisi superskrip tetapi tanpa subskrip, penafsirannya adalah 'persis jumlah segmen itu'. Jadi, $\mathrm{K}^{1}$ berarti persis satu konsonan dan sama dengan $\mathrm{K} ; \mathrm{K}^{2}$, persis dua konsonan dan sama dengan $\mathrm{KK}$; dan seterusnya. 


\section{PENUTUP}

Berdasarkan dari pembahasan pada Bab sebelumnya tentang Kaidah-kaidah Fonologis, maka penulis dapat menyimpulkan beberapa hal sebagai berikut :

a. Apabila segmen mengalami perubahan, kita ingin mengetahui tiga hal, yaitu: (1) segmen mana yang akan berubah, (2) bagaimana segmen itu berubah, dan (3) dalam kondisi apa segmen itu berubah.

b. Kurung kurawal merupakan peranti yang digunakan dalam kaidah untuk merujuk ke lingkungan alternatif.

c. Tanda kurung digunakan sebagai peranti formal untuk meringkas dua kaidah yang serupa, apabila kaidah yang satu berisi spesifikasi yang tidak terdapat dalam kaidah lain.

d. Pelesapan dinyatakan dengan $\varnothing$, simbol nol. Segmen yang mengalami pelesapan muncul disebelah kiri tanda panah, dan $\varnothing$ di sebelah kanan.

e. Kaidah perpaduan, yaitu dua segmen menjadi satu.

f. Disimilasi adalah proses yang terjadi apabila dua segmennya menjadi kurang serupa satu sama lain.

g. Notasi variabel digunakan untuk jenis kaidah khusus yang disebut kaidah pertukaran. Semua kaidah ini mempunyai bentuk: $[\alpha \mathrm{X}] \rightarrow[-\alpha \mathrm{X}]$. 


\section{DAFTAR PUSTAKA}

Alwasilah, A. Chaedar. 1985. Beberapa Madhab dan Dikotomi Teori Linguistik. Bandung: Angkasa.

Amanto, B. S., Umanailo, M. C. B., Wulandari, R. S., Taufik, T., \& Susiati, S. (2019). Local Consumption Diversification. Int. J. Sci. Technol. Res, 8(8), 1865-1869.

Chaer, Abdul. 2014. Linguistik Umum. Jakarta: Rineka Cipta.

Djamudi, N. L., Nurlaela, M., Nazar, A., Nuryadin, C., Musywirah, I., \& Sari, H. (2019, October). Alternative social environment policy through educational values in Kafi'a's customary speech to the kaledupa community of Wakatobi Island, Indonesia. In IOP Conference Series: Earth and Environmental Science (Vol. 343, No. 1, p. 012118). IOP Publishing.

Harziko, H., Said, I. M., \& Darwis, K. (2018). FOLLOW THE EVENTS IN THE INDONESIAN LANGUAGE EXPRESSIVE SAID TRANSACTION IN THE TRADITIONAL MARKET TOWN OF BAUBAU. JURNAL ILMU BUDAYA, 6(1).

Iye, R., \& Susiati, S. (2018). NILAI EDUKATIF DALAM NOVEL SEBAIT CINTA DI BAWAH LANGIT KAIRO KARYA MAHMUD JAUHARI ALI (Educative Values in Sebait Cinta di Bawah Langit Kairo by Mahmud Jauhari Ali). Sirok Bastra, 6 (2), 185-191.

Mufidah, N., \& Tahir, S. Z. B. (2018). Empowering E-Learning As An Interactive Teaching For Arabic Learners. Lisanudhad, 5(2), 57-72.

Salikin, H., Bin-Thahir, S. Z., \& Emelia, C. (2018). SKKD No. 531/UN25. 5.1/TU. 3/2018" The Higher Achiever Students' Strategies in English Learning".

Schane, Sanford A. 1992. Fonologi Generatif. Jakarta: Summer Institute of Linguistic.

Susiati, S. (2018). Homonim bahasa kepulauan tukang besi dialek kaledupa di kabupaten wakatobi [the homonymon of tukang besi island languange in kaledupa dialect at wakatobi regency]. Totobuang, 6(1), 109, 123.

Susiati, S., Iye, R., \& Suherman, L. O. A. (2019). Hot Potatoes Multimedia Applications in Evaluation of Indonesian Learning In SMP Students in Buru District. ELS Journal on Interdisciplinary Studies in Humanities, 2(4), 556-570.

Susiati, S., \& Iye, R. (2018). Kajian Geografi Bahasa dan Dialek di Sulawesi Tenggara: Analisis Dialektometri. Gramatika: Jurnal Ilmiah Kebahasaan dan Kesastraan. 6 (2), 137-151.

Sam, B., Iye, R., Ohoibor, M., Umanailo, M. C. B., Rusdi, M., Rahman, A. B. D., \& Hajar, I. (2019). Female Feminism in the Customary Island of Buru. Int. J. Sci. Technol. Res, 8(8), 1877-1880.

Bin-Tahir, S. Z., Bugis, R., Masniati, A., Tenriawali, A. Y., Azwan, A., \& Oktavianti, D. C. (2020, January). The Role of Local Language in Intercultural Communication among Societies of Buru Island. In Proceeding of USN Kolaka-ADRI International Conference on Sustainable Coastal-Community Development (Vol. 1).

Sahid, A., Amirullah, I., Azis, A., Rachman, A. A., \& Bin-Tahir, S. Z. (2019, November). Application of Bureaucratic Accountability in Public Service. In Eastern Regional Organization for Public Administration Conference (EROPA 2018). Atlantis Press.

Mufidah, N., Suryawati, D., Sa'adah, N., \& Tahir, S. Z. B. (2019). LEARNING ARABIC WRITING SKILL BASED ON DIGITAL PRODUCTS. Ijaz Arabi Journal of Arabic Learning, 2(2).

Farida, U., \& Bin-Tahir, S. Z. (2019, October). Bureaucratic reform of tourism sector public services in Tana Toraja Regency. In IOP Conference Series: Earth and Environmental Science (Vol. 340, No. 1, p. 012045). IOP Publishing.

Bin-Tahir, S. Z., Atmowardoyo, H., Dollah, S., Rinantanti, Y., \& Suriaman, A. (2018). 
MULTILINGUAL AND MONO-MULTILINGUAL STUDENTS'PERFORMANCE IN ENGLISH SPEAKING. Journal of Advanced English Studies, 1(2), 32-38.

Bin-Tahir, S. Z., Suriaman, A., \& Rinantanti, Y. (2019). Designing English Syllabus for Multilingual Students at Pesantren Schools. Asian EFL Journal, 23(3.3), 5-27.

Bin Tahir, S. Z. (2015). Multilingual behavior of Pesantren IMMIM students in Makassar. Asian EFL Journal, 86, 45-64.

Amri, M., Afifuddin, A., \& Bin-Tahir, S. Z. (2018). Religious Pluralism of the Indonesian Traditional Islamic Education Institutions. The Journal of Social Sciences Research, 4(12), 446-450.

Bin Tahir, S. Z. (2017). Multilingual teaching and learning at Pesantren Schools in Indonesia. Asian EFL Journal, 89, 74-94.

Bin-Tahir, S. Z., Saidah, U., Mufidah, N., \& Bugis, R. (2018). The impact of translanguaging approach on teaching Arabic reading in a multilingual classroom. Ijaz Arabi Journal of Arabic Learning, 1(1).

Bin-Tahir, S. Z., Bugis, R., \& Tasiana, R. (2017). Intercultural Communication of a Multicultural Family in Buru Regency. Lingual: Journal of Language and Culture, 9(2), 8 .

Nurhayati, N., \& Said, I. (2019). Emosi Verbal Suku Bajo Sampela. Sosial Budaya, 16(2), 114-126.

Aswad, H., Nurhayaty, N., \& Said, I. (2018). THE USE OF MANTRA IN THE TRADITION OF MAITAI ALLO MACOA IN ONGLO PEOPLE CAMPALAGIAN SUBDISTRICT POLMAN REGENCY: A REVIEW OF THE SEMIOTICS. JURNAL ILMU BUDAYA, 6(1).

Iye, R. (2018). Tuturan emosi mahasiswa kota baubau dalam ranah demonstrasi [emotional speech of the students in baubau city in the demonstration]. TOTOBUANG, 6 (1), $125,138$.

Iye, R., \& Susiati, S. (2018). NILAI EDUKATIF DALAM NOVEL SEBAIT CINTA DI BAWAH LANGIT KAIRO KARYA MAHMUD JAUHARI ALI (Educative Values in Sebait Cinta di Bawah Langit Kairo by Mahmud Jauhari Ali). Sirok Bastra, 6 (2), 185-191.

Susiati, S., Iye, R., \& Suherman, L. O. A. (2019). Hot Potatoes Multimedia Applications in Evaluation of Indonesian Learning In SMP Students in Buru District. ELS Journal on Interdisciplinary Studies in Humanities, 2(4), 556-570.

Iye, R. J1 Prof Dr HAR Basalamah No, and Namlea-Kab Buru.". TUTURAN DALAM PROSESI LAMARAN PERNIKAHAN DI TOMIA KABUPATEN WAKATOBI." Kontemporer. Bandung: PT Remaja.

Susiati, S., \& Iye, R. (2018). Kajian Geografi Bahasa dan Dialek di Sulawesi Tenggara: Analisis Dialektometri. Gramatika: Jurnal Ilmiah Kebahasaan dan Kesastraan, 6(2), 137-151.

Susiati, S., \& Iye, R. (2018). Kajian Geografi Bahasa dan Dialek di Sulawesi Tenggara: Analisis Dialektometri. Gramatika: Jurnal Ilmiah Kebahasaan dan Kesastraan. 6 (2), 
137-151.

Iye, R., Susiati, S., \& Karim, K. (2020). Citra Perempuan dalam Iklan Sabun Shinzui. Sang Pencerah: Jurnal Ilmiah Universitas Muhammadiyah Buton, 6(1), 1-7.

Iye, R. (2018). Tuturan dalam Prosesi Lamaran Pernikahan di Tomia Kabupaten Wakatobi. Jurnal Totobuang, 6(2).

Iye, R. Harziko. NILAI-NILAI MORAL DALAM TOKOH UTAMA PADA NOVEL SATIN MERAH KARYA BRAHMANTO ANINDITO DAN RIE YANTI. TELAGA BAHASA,(7), 2, 195-206.

Susiati, Y. T. Risman Iye. A. Kesantunan Imperatif Bahasa Indonesia Suku Bajo Sampela:

Balai Pembinaan dan Pengembangan Bahasa. 2018. Kongres Bahasa Indonesia (No. 12, pp. 1-6). Report.

UNIQBU, P. (2019). TUTURAN EMOSI MAHASISWA KOTA BAU BAU.

PSP2M, T., \& Iye, R. TUTURAN EMOSI MAHASISWA KOTA BAU BAU.

Umanailo, M. C. B., Hentihu, I., Umanailo, R., Nawawi, M., Pulhehe, S., Ohoibor, M., ... \& Bugis, R. I. K. I. (2018). Pemahaman Untuk Desa.

Umanailo, M. Chairul Basrun, Idrus Hentihu, Rosita Umanailo, Mansyur Nawawi, Sukainap Pulhehe, Mirja Ohoibor, Mohammad Faisal Sangadji et al. "Pemahaman Untuk Desa." (2018).

BURU, U. I. MODEL KOOPERATIF LEARNING TIPE STAD DALAM MENINGKATKAN KEMAMPUAN MENGAPRESIASI CERITA FIKSI DI SD NEGERI 1 NAMLEA.

Iye, R. (2018). Tuturan emosi mahasiswa kota baubau dalam ranah demonstrasi.

No, J. S. Q., Baruga, K. K., Bassalama, J. P. A., \& Si, M. PRAANGGAPAN PAMFLET SOSIALISASI PELESTARIAN LINGKUNGAN DI KABUPATEN WAKATOBI.

Djunaidi, F. G., Azwan, A. Y. T., Iye, R., \& bin Tahir, S. Z. Decks Range Gola Village Community Begun District Buton District North.

Buru, K. M. S. PENGARUH MOTIVASI BELAJAR DI SMA NEGERI 2 BURU.

No, J. S. Q., Baruga, K. K., Bassalama, J. P. A., \& Si, M. PRAANGGAPAN PAMFLET SOSIALISASI PELESTARIAN LINGKUNGAN DI KABUPATEN WAKATOBI.

BURU, U. I. MODEL KOOPERATIF LEARNING TIPE STAD DALAM MENINGKATKAN KEMAMPUAN MENGAPRESIASI CERITA FIKSI DI SD NEGERI 1 NAMLEA.

YANTI, KBADANRI. "NILAI-NILAI MORAL DALAM TOKOH UTAMA PADA NOVEL SATIN MERAH."

Buru, K. M. S. PENGARUH MOTIVASI BELAJAR DI SMA NEGERI 2 BURU.

Djunaidi, F. G., Azwan, A. Y. T., Iye, R., \& bin Tahir, S. Z. Decks Range Gola Village Community Begun District Buton District North.

Iye, R. DEIKSIS MASYARAKAT BONEGUNU KABUPATEN BUTON UTARA.

YANTI, K. NILAI-NILAI MORAL DALAM TOKOH UTAMA PADA NOVEL SATIN MERAH.

Said, Ikhwan. "EMOSI VERBAL SUKU BAJO SAMPELA."

NAMLEA, F. D. D. S. K. PERWUJUDAN ADJEKTIVA BAHASA SULA DIALEK. 
YANTI, K. NILAI-NILAI MORAL DALAM TOKOH UTAMA PADA NOVEL SATIN MERAH.

BURU, U. I. MODEL KOOPERATIF LEARNING TIPE STAD DALAM MENINGKATKAN KEMAMPUAN MENGAPRESIASI CERITA FIKSI DI SD NEGERI 1 NAMLEA.

Susiati, S. (2020). Fenomena Tuturan Emosi Verbal Bahasa Indonesia Suku Bajo Sampela. Susiati, S. (2020). Fenomena Tuturan Emosi Verbal Bahasa Indonesia Suku Bajo Sampela. Susiati, S. (2020). Fenomena Tuturan Emosi Verbal Bahasa Indonesia Suku Bajo Sampela. Susiati, S. (2020). Pengaplikasian Multimedia Hot Potatoes Dalam Evaluasi Pembelajaran Bahasa Indonesia Pada Siswa SMP Negeri 9 Buru.

BURU, I. PENGEMBANGAN APLIKASI MULTIMEDIA HOT POTATOES DALAM EVALUASI PEMBELAJARAN BAHASA INDONESIA PADA SISWA SMP NEGERI 9 BURU (DEVELOPMENT OF HOT POTATOES MULTIMEDIA APPLICATIONS IN EVALUATION OF INDONESIAN LEARNING IN SMP 9 STUDENTS.

Susiati, S. (2020). Kaidah Fonologi Bahasa Indonesia.

BURU, I. PENGEMBANGAN APLIKASI MULTIMEDIA HOT POTATOES DALAM EVALUASI PEMBELAJARAN BAHASA INDONESIA PADA SISWA SMP NEGERI 9 BURU (DEVELOPMENT OF HOT POTATOES MULTIMEDIA APPLICATIONS IN EVALUATION OF INDONESIAN LEARNING IN SMP 9 STUDENTS.

FONOLOGI, M. K. KAIDAH-KAIDAH FONOLOGI.

Susiati, S. (2020). Fenomena Tuturan Emosi Verbal Bahasa Indonesia Suku Bajo Sampela. Susiati, S. (2020). Kesantunan Imperatif Bahasa Melayu Ambon.

Buru, K. M. S. PENGARUH MOTIVASI BELAJAR DI SMA NEGERI 2 BURU.

Susiati, Y. T. Risman Iye. A. Kesantunan Imperatif Bahasa Indonesia Suku Bajo Sampela: Balai Pembinaan dan Pengembangan Bahasa. 2018. Kongres Bahasa Indonesia (No. 12, pp. 1-6). Report.

Iye, R. H. NILAI-NILAI MORAL DALAM TOKOH UTAMA PADA NOVEL SATIN MERAH KARYA BRAHMANTO ANINDITO DAN RIE YANTI. TELAGA BAHASA,(7), 2, 195-206.

Iye, R. J1 Prof Dr HAR Basalamah No, and Namlea-Kab Buru.". TUTURAN DALAM PROSESI LAMARAN PERNIKAHAN DI TOMIA KABUPATEN WAKATOBI." Kontemporer. Bandung: PT Remaja.

Iye, R. H. NILAI-NILAI MORAL DALAM TOKOH UTAMA PADA NOVEL SATIN MERAH KARYA BRAHMANTO ANINDITO DAN RIE YANTI. TELAGA BAHASA,(7), 2, 195-206.

Susiati, S., \& Iye, R. (2018). Kajian Geografi Bahasa dan Dialek di Sulawesi Tenggara: Analisis Dialektometri. Gramatika: Jurnal Ilmiah Kebahasaan dan Kesastraan. 6 (2), 137-151. 
Imron, Ali. 2009 . Stilistika, Teori, Metode, dan Aplikasi Pengkajian Estetika Bahasa. Solo: Cakra Books.

Karsono. 2011. Ragam Gaya Bahasa. Tersedia di http://karsonojawul.blog.uns.ac.id//. Diunduh pada tanggal 1 Maret 2012.

Keraf, Gorys.2007. Diksi dan Gaya Bahasa. Jakarta : PT. Gramedia Pustaka Utama Murtono. 2010. Menuju Kemahiran Berbahasa Indonesia. Surakarta : UNS Press. Nurgiyantoro, Burhan. 2002. Teori Pengkajian Fiksi. Yogyakarta: Gaja Mada University Press.

Pusat Pembinaan dan Pengembangan Bahasa. 2007. Pedoman Umum Ejaan Bahasa Indonesia yang Disempurnakan. Tera, Yogyakarta.

Ratna, Nyoman Kutha. 2009. Stilistika kajian Puitika Bahasa, Sastra, dan Budaya.

Yogyakarta : Pustaka Pelajar

Saefu, Zaman. 2011. Macam-Macam Gaya Bahasa Indonesia. Tersedia di http://situsbahasa.com//. Diunduh pada tanggal 1 Maret 2012.

Sudaryat, Ndang. 1986. Ringkasan Bahasa Indonesia. Bandung: Ganeca Exact Posted by danriris in Artikel, Tata Bahasa. Tagged: Gaya Bahasa, Jenis Gaya Bahasa.

Iye, R., Susiati, S., \& Karim, K. (2020). Citra Perempuan dalam Iklan Sabun Shinzui. Sang Pencerah: Jurnal Ilmiah Universitas Muhammadiyah Buton, 6(1), 1-7.

Susiati, Y. T. Risman Iye. A. Kesantunan Imperatif Bahasa Indonesia Suku Bajo Sampela: Balai Pembinaan dan Pengembangan Bahasa. 2018. Kongres Bahasa Indonesia (No. 12, pp. 1-6). Report.

Taufik, T. (2019). Strategi AMBT untuk Meningkatkan Kemampuan Membaca Pemahaman Interpretatif Siswa Kelas IV SD Negeri 3 Namlea Kabupaten Buru. Sang Pencerah: Jurnal Ilmiah Universitas Muhammadiyah Buton, 5(2), 53-62.

Verhaar, J. W. M. 1991. Pengantar Linguistik. Yogyakarta: Gadjah Mada University Press. Yusdianti, A. (2020). THE REPRESENTATION VICTIMS OF VIOLENCE IN TRIBUN TIMUR ONLINE NEWS TEXT: CRITICAL DISCOURSE ANALYSIS. 